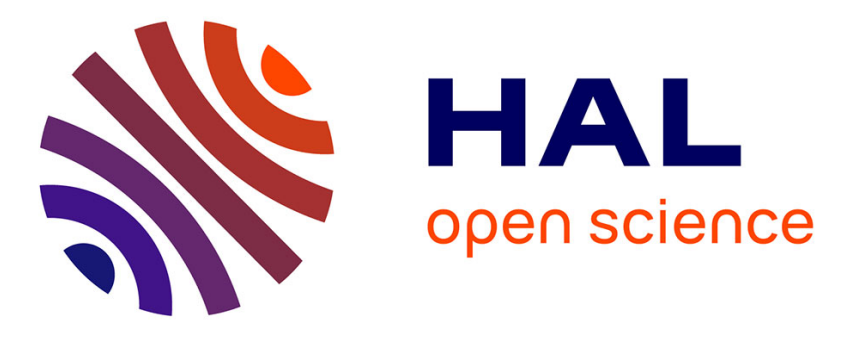

\title{
Impact of dose-rate on the low-dose hyper-radiosensitivity and induced radioresistance (HRS/IRR) response.
}

Charles Thomas, Jennifer Martin, Clément Devic, Elke Bräuer-Krisch, Michel Diserbo, Juliette Thariat, Nicolas Foray

\section{To cite this version:}

Charles Thomas, Jennifer Martin, Clément Devic, Elke Bräuer-Krisch, Michel Diserbo, et al.. Impact of dose-rate on the low-dose hyper-radiosensitivity and induced radioresistance (HRS/IRR) response.. International Journal of Radiation Biology, 2013, 89 (10), pp.813-22. 10.3109/09553002.2013.800248 . inserm-00830982

\section{HAL Id: inserm-00830982 https://www.hal.inserm.fr/inserm-00830982}

Submitted on 4 Jun 2014

HAL is a multi-disciplinary open access archive for the deposit and dissemination of scientific research documents, whether they are published or not. The documents may come from teaching and research institutions in France or abroad, or from public or private research centers.
L'archive ouverte pluridisciplinaire $\mathbf{H A L}$, est destinée au dépôt et à la diffusion de documents scientifiques de niveau recherche, publiés ou non, émanant des établissements d'enseignement et de recherche français ou étrangers, des laboratoires publics ou privés. 


\section{Abstract}

Purpose: To ask whether dose-rate influences low-dose hyperradiosensitivity and induced radioresistance (HRS/IRR) response in rat colon carcinoma progressive (PRO) and regressive (REG) cells. Methods: Clonogenic survival was applied to tumorigenic PRO and non-tumorigenic REG cells irradiated with ${ }^{60} \mathrm{Co} \gamma$-rays at 0.0025-500 mGy.min ${ }^{-1}$. Both clonogenic survival and nonhomologous end-joining (NHEJ) pathway involved in DNA double-strand breaks (DSB) repair assays were applied to PRO cells irradiated at $25 \mathrm{mGy} \cdot \mathrm{min}^{-1}$ with $75 \mathrm{kV}$ X-rays only.

Results: Irrespective of dose-rates, marked HRS/IRR responses were observed in PRO but not in REG cells. For PRO cells, the doses at which HRS and IRR responses are maximal were dependent on dose-rate; conversely exposure times during which HRS and IRR responses are maximal ( $t_{\text {HRSmax }}$ and $\left.t_{\text {IRRmax }}\right)$ were independent of dose-rate. The $t_{\text {HRSmax }}$ and $t_{\text {IRRmax }}$ values were $23 \pm 5 \mathrm{~s}$ and $66 \pm 7 \mathrm{~s}$ (mean \pm standard error of the mean [SEM], $n=7$ ), in agreement with literature data. Repair data show that $t_{\text {HRSmax }}$ may correspond to exposure time during which NHEJ is deficient while $t_{\text {IRRmax }}$ may correspond to exposure time during which NHEJ is complete.

Conclusion: HRS response may be maximal if exposure times are shorter than $t_{\text {HRSmax }}$ irrespective of dose, dose-rate and cellular model. Potential application of HRS response in radiotherapy is discussed.

\section{Keywords: Hyper-radiosensitivity (HRS) response, induced radioresistance (IRR) response, dose-rate, DSB repair, tumor cells, radiotherapy}

\section{Introduction}

It is now well documented that cells irradiated at single low-dose fraction can show marked hyper-radiosensitivity (HRS) and induced radioresistance (IRR) response (Table I). The HRS/IRR response is a representative example of a non-linear dose-dependent event. The HRS/ IRR response was originally observed in vivo in mice using acute skin tissue damage as an endpoint (Joiner et al. 1986). Thereafter, the HRS response, mostly observed by using in vitro survival assay in single tumor cells, was shown to result in a significant reduction of about $25 \%$ cell survival between 0.1 and $0.8 \mathrm{~Gy}$. The dose at which the maximal HRS response is observed $\left(D_{\text {HRSmax }}\right)$ depends on the cell line (Table I). The HRS response generally occurs in tumor or transformed cells (Marples and Collis 2008). At doses higher than $\mathrm{D}_{\text {HRSmax }}$, cell survival increases progressively and this phenomenon was called IRR response. Despite a number of studies, the mechanisms of the HRS and IRR responses, whether taken separately or together, remain unclear. It has been suggested that the HRS response may depend upon changes in chromatin conformation (Joiner et al. 2001), failure of the Ataxia Telangiectasia Mutated protein (ATM)-dependent $\mathrm{G}_{2} / \mathrm{M}$ checkpoint (Marples et al. 2004), or defects in DNA double-strand breaks (DSB) (Vaganay-Juery et al. 2000, Short et al. 2005). It was notably suggested that the HRS response may reflect apoptotic death of tumor cells that failed to arrest in cell cycle whereas the IRR response may reflect early cell cycle $G_{2}$-phase arrest allowing time for repair and increased cell survival (Marples and Collis 2008). In 2008, we pointed out that the HRS response may be caused by impairments in the non-homologous end-joining (NHEJ) repair pathway that targets $G_{1}$ cells and in lack of control of the RAD51-dependent recombination repair pathway that targets $S-G_{2} / M$ cells; the consequences of such impairments are failure to arrest in the cell cycle, propagation of damage through the cell cycle, mitotic death, but not p53-dependent apoptosis (Thomas et al. 2008).

The HRS/IRR response is more marked in cells displaying genomic instability: In fact, this response was mostly

\footnotetext{
*The authors dedicate this work to Bernard Fertil for his contribution to radiobiology.

Correspondence: Charles Thomas, Inserm U1052, Centre de Recherche en Cancérologie de Lyon, 28 Rue Laënnec, 69008 Lyon, France. Tel: + 33698261603 , E-mail: charles.thomas1@sfr.fr

(Received 20 November 2012; revised 10 April 2013; accepted 22 April 2013)
} 
Table I. Major radiobiological studies on HRS/IRR response. Most studies used tumor cell lines. Few studies used transformed cell lines (V79, CHO-K1, MR4, GM0639, EBS7YZ5) or a normal fibroblast cell line (BJ). The doses at which the maximal HRS and IRR response are observed $\left(D_{\text {HRSmax }}, D_{\text {IRRmax }}\right)$ and the time at which the maximal HRS and IRR response are observed $\left(t_{\text {HRSmax, }}, t_{\text {IRRmax }}\right)$ were obtained from survival data reported in the quoted references.

\begin{tabular}{|c|c|c|c|c|c|c|c|}
\hline Irradiation & $\begin{array}{c}\text { Dose rate } \\
\left(\mathrm{mGy} \cdot \mathrm{min}^{-1}\right)\end{array}$ & $\begin{array}{c}\mathrm{D}_{\text {HRSmax }} \\
\text { (mGy) }\end{array}$ & $\mathrm{t}_{\mathrm{HRS \operatorname {max }}}(\mathrm{s})$ & $\begin{array}{l}\mathrm{D}_{\text {IRRmax }} \\
\text { (mGy) }\end{array}$ & $\mathrm{t}_{\mathrm{IRR \operatorname {max }}}(\mathrm{s})$ & Cell line & Reference \\
\hline 240 KV X-rays & 180 & 200 & 67 & 600 & 200 & Human HT29 & Lambin et al. (1993) \\
\hline 240 KV X-rays & 118 & 120 & 40 & 500 & 167 & Human Bel1 & Lambin et al. (1996) \\
\hline $240 \mathrm{KV}$ X-rays & 180 & 250 & 83 & 500 & 167 & Human RT112 & Lambin et al. (1996) \\
\hline${ }^{60}$ Co $\gamma$-rays & 580 & $200^{*}$ & 21 & 600 & 62 & $\begin{array}{l}\text { Human variant } 1 \\
\text { (T1p26) }\end{array}$ & Thomas et al. (1997) \\
\hline${ }^{60} \mathrm{Co} \gamma$-rays & 580 & $100^{*}$ & 10 & 200 & 21 & Human clone 4 (T1C3) & Thomas et al. (1997) \\
\hline${ }^{60} \mathrm{Co} \gamma$-rays & 1000 & 440 & 26 & 750 & 45 & Rodent V79 & Tsoulou et al. (2001) \\
\hline $9.5 \mathrm{Mev} \alpha$-rays & 1000 & 340 & 20 & 500 & 30 & Rodent V79 & Tsoulou et al. (2001) \\
\hline 300 KV X-rays & 500 & 110 & 13 & 500 & 60 & Rodent subline CHO-K1 & Barkowiak et al. (2001) \\
\hline${ }^{60} \mathrm{Co} \gamma$-rays & 2000 & 100 & 3 & 500 & 15 & Human BMG1 & Chandna et al. (2002) \\
\hline${ }^{60} \mathrm{Co} \gamma$-rays & 2000 & 200 & 6 & 500 & 15 & Human U87 & Chandna et al. (2002) \\
\hline${ }^{60} \mathrm{Co} \gamma$-rays & 2000 & 300 & 9 & 500 & 15 & Human PECA4451 & Chandna et al. (2002) \\
\hline${ }^{60} \mathrm{Co} \gamma$-rays & 2000 & 300 & 9 & 1000 & 30 & Human PECA4197 & Chandna et al. (2002) \\
\hline 10 MV X-rays & 2430 & 800 & 20 & 950 & 23 & Human G5 & $\begin{array}{l}\text { Beauchesne et al. } \\
\text { (2003) }\end{array}$ \\
\hline 10 MV X-rays & 2430 & 700 & 17 & 800 & 20 & Human G111 & $\begin{array}{l}\text { Beauchesne et al. } \\
\text { (2003) }\end{array}$ \\
\hline 10 MV X-rays & 2430 & 700 & 17 & 950 & 23 & Human G142 & $\begin{array}{l}\text { Beauchesne et al. } \\
\text { (2003) }\end{array}$ \\
\hline 10 MV X-rays & 2430 & 800 & 20 & 950 & 23 & Human G152 & $\begin{array}{l}\text { Beauchesne et al. } \\
\text { (2003) }\end{array}$ \\
\hline${ }^{137} \mathrm{Cs} \gamma$-rays & 220 & 100 & 27 & 200 & 54 & Human A549 & Enns et al. (2004) \\
\hline${ }^{137} \mathrm{Cs} \gamma$-rays & 220 & 250 & 68 & 750 & 205 & Human T98G & Enns et al. (2004) \\
\hline 320 KV X-rays & 750 & 180 & 14 & 300 & 24 & Rodent MR4 & Wykes et al. (2006) \\
\hline 320 KV X-rays & 750 & 105 & 8 & 400 & 32 & Human M059K & Wykes et al. (2006) \\
\hline 320 KV X-rays & 750 & 140 & 11 & 400 & 32 & Human EBS7YZ5 & Wykes et al. (2006) \\
\hline${ }^{60} \mathrm{Co} \gamma$-rays & 660 & 280 & 25 & 1000 & 91 & Human T47D & Edin et al. (2007) \\
\hline 320 KV X-rays & 750 & 310 & 25 & 750 & 60 & Human T98G & Krueger et al. (2007a) \\
\hline${ }^{60} \mathrm{Co} \gamma$-rays & 1800 & 100 & 3.3 & 300 & 10 & Human BJ & Nuta \& Darroudi (2008) \\
\hline${ }^{60} \mathrm{Co} \gamma$-rays & 500 & 190 & 23 & 500 & 60 & Rodent PRO & Thomas et al. (2008) \\
\hline 200 KV X-rays & 500 & 100 & 12 & 300 & 36 & Human GM0639 & Xue et al. (2009) \\
\hline $290 \mathrm{Mev}{ }^{6} \mathrm{C}$ & 500 & 170 & 20 & 400 & 48 & Human GM0639 & Xue et al. (2009) \\
\hline $62 \mathrm{Mev}$ protons & 15000 & 2000 & 8 & 4000 & 16 & Human HTB140 & Petrovic et al. (2010) \\
\hline $250 \mathrm{KV}$ X-rays & 855 & 250 & 18 & 500 & 35 & Human A549 & Wera et al. (2012) \\
\hline
\end{tabular}

*These numbers correspond to a reanalysis of our raw data for exposure times less than $10 \mathrm{~min}$.

observed in tumor and in some transformed normal cell lines (Table I). Furthermore, we have previously reported that human and rodent tumorigenic cells with high metastatic potential preferentially show the HRS response (Thomas et al. 1997, 2008). We have therefore suggested that the HRS response may find applications in radiotherapy, notably for unvascularized and isolated micrometastasis (Thomas et al. 2001, 2007). On the other hand, the occurrence of the HRS/IRR response in primary normal cells is still controversial and may depend on the differentiation and/or proliferation status. As an example, six among nine primary explants of uroepithelium showed HRS/IRR response with a 14 days post-irradiation proliferative assay as endpoint (Mothersill et al. 1995). The HRS/IRR response assessed by micronuclei assay was also observed in about $10 \%$ of primary keratinocytes and fibroblasts from cervix carcinoma patients (Slonina et al. 2007).

Interestingly, the literature shows that the HRS/IRR response of tumor cells irradiated with low-energy transfer (LET) radiation was investigated at dose-rates ranging from 0.18-2.43 Gy. $\mathrm{min}^{-1}$ (Table I). These data raise the question of a dose-rate-dependence of the HRS/IRR response. In order to answer this question, we investigated clonogenic cell survival at seven dose-rates (from 0.0025-500 mGy. $\min ^{-1}$ ) in two rat colon carcinoma sublines progressive
(PRO) and regressive (REG) cells that were shown to be HRS positive and negative, respectively (Thomas et al. 2008).

\section{Materials and methods}

\section{Cells and irradiation}

Rat colon carcinoma PRO and REG cells were kindly provided by Dr F. Martin (Dijon, France). PRO and REG sublines were isolated from the parental tumor cell line DHD-K12, established from dimethylhydrazine-induced colon carcinoma in syngeneic BDIX rats (Martin et al. 1983). PRO and REG sublines were isolated according to their sensitivity to trypsin-mediated detachment from plastic surface (PRO subline is more trypsin-resistant than REG subline). When grafted subcutaneously in BDIX rats, REG cells produced regressive tumors disappearing within 3-4 weeks while PRO cells produced progressive tumors in $60 \%$ of animals with metastases to lungs, kidney or lymph nodes (Martin et al. 1983). PRO and REG sublines were cultured in Roswell Park Memorial Institute (RPMI) 1640 medium with $2 \mathrm{mM}$ glutamine, 10\% decomplemented fetal bovine serum, 1\% [4-(2-hydroxyethyl)1-piperazineethanesulfonic acid] (HEPES) and antibiotics (1\% penicillin, streptomycin) (Gibco-Invitrogen-France, Cergy-Pontoise, France). Cells were mycoplasma-free and 
maintained at $37^{\circ} \mathrm{C}$ at $5 \% \mathrm{CO}_{2}$ for no more than five passages after defrost. For all the assays described below, confluent PRO and REG cultures were softly detached with $0.025 \%$ trypsin and $0.02 \%$ ethylenediaminetetraacetic acid (EDTA) (Gibco-Invitrogen-France, Cergy-Pontoise, France) to obtain single cell suspensions. Since the HRS/IRR response is suppressed under condition of increased cellcell contact (Chandna et al. 2002), the number of aggregates (no more than 5 cells) was kept as low as possible. Irradiations were performed at European Synchrotron Radiation Facility (ESRF, Grenoble, France) with X-rays produced by a clinical irradiator $(75 \mathrm{kV}, 14 \mathrm{~mA})$ at a dose-rate of $25 \mathrm{mGy} /$ min and at Institut de Recherche Biomédicale des Armées (IRBA, Grenoble, France) with ${ }^{60} \mathrm{Co} \gamma$-rays at dose-rates of $230,60,44,25,0.3$ or $0.0025 \mathrm{mGy} \mathrm{min}^{-1}$. This range of doserate corresponds to space radiation $\left(0.0025 \mathrm{mGy} \cdot \mathrm{min}^{-1}\right)$, nuclear medicine $\left(0.3 \mathrm{mGy} \cdot \mathrm{min}^{-1}\right)$, radiodiagnosis (25, 44, $60 \mathrm{mGy} \cdot \mathrm{min}^{-1}$ ) and radiotherapy (230 $\mathrm{mGy} \cdot \mathrm{min}^{-1}$ ). These four groups of dose-rate are evenly distributed on log scale. The $25 \mathrm{mGy} \cdot \mathrm{min}^{-1}$ dose-rate was chosen to evaluate cell survival at two different clinically relevant radiation type (Cobalt $60 \gamma$-rays and $75 \mathrm{kV} \mathrm{X-rays).} \mathrm{Dose}$ and their homogeneity in the irradiation field were routinely verified with Physikalisch Technische Werkstatten (PTW) ionization chambers $\left(0.3 \mathrm{~cm}^{3}\right.$ type TM23332 for dose-rates higher than $25 \mathrm{mGy} \cdot \mathrm{min}^{-1}$ and $30 \mathrm{~cm}^{3}$ type TM23361 for dose-rates lower than $25 \mathrm{mGy} \cdot \mathrm{min}^{-1}$ at IRBA and semiflex chamber type TW31010-03907 for dose-rate of $25 \mathrm{mGy} \cdot \mathrm{min}^{-1}$ at ESRF). The relative dose error was $10 \%$. The error committed on exposure times (given digitally) was negligible. For all the dose-rates applied in this study, the exposure times were always shorter than $10 \mathrm{~min}$ (Table II).

\section{Clonogenic survival assay}

Clonogenic survival was assessed as previously described (Thomas et al. 2008). Briefly, 250 cells were seeded in sixwell plates and irradiated $24 \mathrm{~h}$ after plating at various dose-rates. Colonies were fixed and stained with standard crystal violet solution (Sigma-Aldrich-France, l'Isle d'Abeau, France) after 10 days incubation without change of medium. Only colonies showing more than 50 cells were considered. Plating efficiencies of unirradiated REG and PRO cells at IRBA were $39 \pm 6 \%$ (mean \pm standard error of the mean [SEM], $n=8$ independent experiments) and $25 \pm 2 \%$ (mean \pm SEM, $n=17$ independent experiments), respectively. Plating efficiencies of unirradiated REG and PRO cells at

Table II. Dose-rates, exposure times and doses investigated in this study with ${ }^{60} \mathrm{Co} \gamma$-rays (data shown in Figure 1A-F).

\section{Dose-rate}

(mGy/min)

$230 \quad 2.6 ; 6.5 ; 13 ; 26 ; 65 ; 78 ; 130 \quad 10 ; 25 ; 50 ; 100 ; 250 ; 300 ; 500$

$60 \quad 5 ; 10 ; 25 ; 50 ; 100 ; 200 ; \quad 5 ; 10 ; 25 ; 50 ; 100 ; 200 ; 300$; $300 ; 500$

44

25

0.3

$7 ; 14 ; 27 ; 70 ; 140 ; 270 ; 341$

$6 ; 12 ; 24 ; 60 ; 120 ; 180 ; 240$

$5 ; 10 ; 20 ; 40 ; 100 ; 200$

$2.4 ; 6 ; 12 ; 24 ; 48 ; 120 ; 240$ 500

$5 ; 10 ; 20 ; 50 ; 100 ; 200 ; 250$

$2.5 ; 5 ; 10 ; 25 ; 50 ; 75 ; 100$ $0.025 ; 0.05 ; 0.1 ; 0.2 ; 0.5,1$ $0.0001 ; 0.00025 ; 0.0005$; $0.001 ; 0.002 ; 0.005 ; 0.01$
ESRF were $29 \pm 3 \%$ (mean \pm SEM, $n=3$ independent experiments) and $14 \pm 1 \%$ (mean \pm SEM, $n=2$ independent experiments), respectively. The impact of cell proliferation before irradiation on HRS response was previously investigated; we showed that the HRS response was similar in PRO cells whether irradiated 2 or $24 \mathrm{~h}$ after plating; cell multiplicity (i.e., the number of cells per colonyforming unit) $24 \mathrm{~h}$ after plating was found to be close to one (Thomas et al. 2008).

\section{Survival curves analysis}

Using the JMP software (version 2.0.5. SAS institute, Cary, NC, USA), the surviving fractions (SF) were fitted to two models: The one population linear-quadratic (LQ) model and the induced repair (IR) model (Thomas et al. 2008) defined by, respectively:

$$
\begin{gathered}
\operatorname{SF}(D)=\mathrm{e}^{-\left(\alpha \cdot D+\beta \cdot D^{2}\right)} \\
\mathrm{SF}(\mathrm{D})=\mathrm{e}^{-\alpha_{\mathrm{r}}\left[1+\left(\frac{\alpha_{\mathrm{s}}}{\alpha_{\mathrm{r}}}-1\right) \cdot \mathrm{e}^{-\frac{\mathrm{D}}{\alpha_{\mathrm{c}}}}\right] \cdot \mathrm{D}-\beta_{\mathrm{r}} \cdot \mathrm{D}^{2}}
\end{gathered}
$$

The IR model is a modified version of the LQ model in which the $\alpha$ term is dependent on dose (D): at very low doses, $\alpha$ is large, and it decreases with increasing dose in an exponential manner at a rate determined by a constant $\mathrm{d}_{\mathrm{c}}$. The parameter $\alpha_{\mathrm{s}}$ represents the initial slope of the survival curve at very low doses; $\alpha_{r}$ represents the initial slope of the survival curve extrapolated from the conventional high-dose response described by the LQ model; $d_{c}$ represents the dose that induced the change from HRS to IRR response and $\beta_{\mathrm{r}}$ represents the distal slope of the survival curve. The occurrence of the HRS/IRR response is mathematically deduced from $\alpha_{s}$ and $\alpha_{r}$ values that do not coincide and $d_{c}$ values significantly greater than zero (Table II). Since some data reported in Table I were not always fitted to the IR model, we deliberately chose to rename the $d_{c}$ parameter $\mathrm{D}_{\text {HRSmax }}$ since it corresponds to the maximal extent of the HRS response. Similarly, we defined the $\mathrm{D}_{\text {IRRmax }}$ parameter that corresponds to the maximal extent of the IRR response (Table I).

\section{Immunofluorescence assay}

The assay which is described elsewhere (Thomas et al. 2008), was applied with minor modifications to measure the number of $\gamma$-pH2AX foci per cell $15 \mathrm{~min}, 1 \mathrm{~h}, 4 \mathrm{~h}$ and $24 \mathrm{~h}$ after irradiation. Briefly, $10^{4}$ cells were seeded on slides in six-well plates and incubated for $24 \mathrm{~h}$ in complete medium at $37^{\circ} \mathrm{C}$. After irradiation at $75 \mathrm{kV} \mathrm{X}$-rays at $10 \mathrm{mGy}$ (24 s) and $100 \mathrm{mGy}(240 \mathrm{~s})$, plates were incubated at $37^{\circ} \mathrm{C}$ for $10 \mathrm{~min}$ and $24 \mathrm{~h}$. Cells were then fixed in paraformaldehyde solution for $15 \mathrm{~min}$ at room temperature and permeabilized for $90 \mathrm{~s}$ at $4^{\circ} \mathrm{C}$ in lysis solution (20 mM HEPES) [pH 7.4], $50 \mathrm{mM} \mathrm{NaCl}, 3 \mathrm{mM} \mathrm{MgCl}_{2}, 300 \mathrm{mM}$ sucrose, 0.5\% Triton X-100) (Sigma-Aldrich-France, l'Isle d'Abeau, France). Primary antibody incubations were performed for $40 \mathrm{~min}$ at $37^{\circ} \mathrm{C}$. Anti- $\gamma-p H 2 A X^{\text {serl39 }}$ antibody (\#05636; Upstate Biotechnology-Euromedex, Mundolsheim, France) was used at 1:800. Incubation with anti-mouse fluorescein 
(green) secondary antibody was performed at $1: 100$ at $37^{\circ} \mathrm{C}$ for $20 \mathrm{~min}$. Slides were mounted in 4',6-diamidino-2phenylindole (DAPI)-stained Vectashield (Abcys, Paris, France) and the number of $\gamma$-pH2AX foci per cell in 126-209 cells (15 min experiments) or 142-198 cells ( $24 \mathrm{~h}$ experiments) were examined with Olympus BX51 fluorescence microscope. DAPI staining permitted to indirectly evaluate yield of $\mathrm{G}_{1}$ cells (nuclei with homogeneous DAPI staining), $S$ cells (nuclei showing numerous $\gamma$-pH2AX foci), $G_{2}$ cells (nuclei with heterogeneous DAPI staining) and metaphase (visible chromosomes). DAPI staining permitted also to quantify the percentage of cells with micronuclei by examining 100 cells at least. In order to avoid any bias by using imaging analysis software, the number of foci per cell was determined after eye-scoring in about 50 cells in G0/ G1 per slide.

(A) DOSE (mGy)

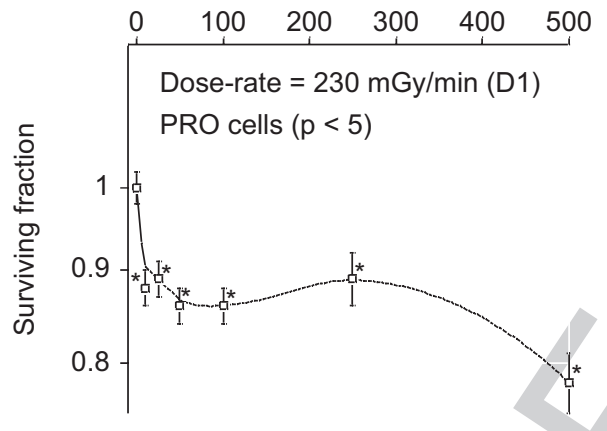

(C)

DOSE (mGy)
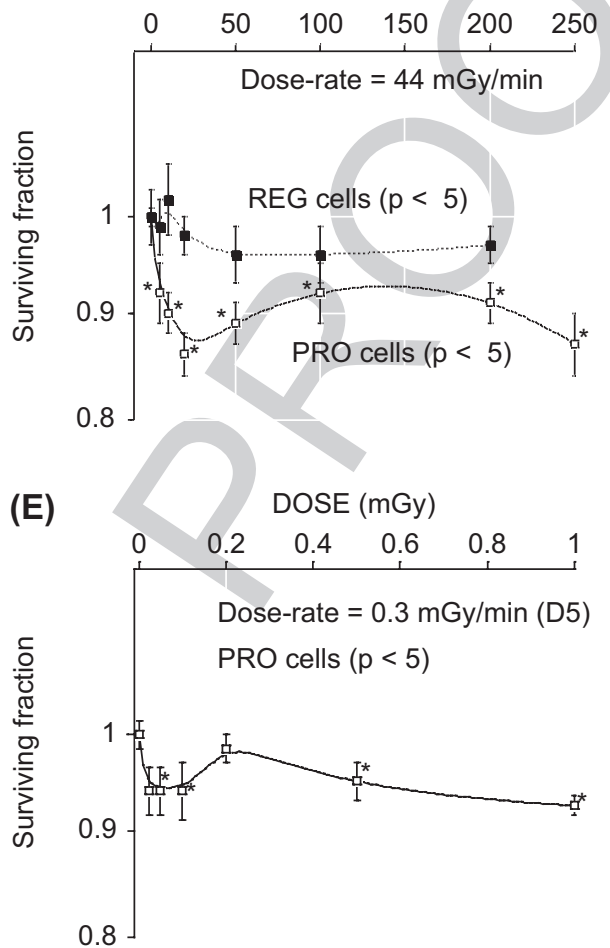

Results

$H R S / I R R$ response of PRO cells irradiated with ${ }^{60} \mathrm{Co} \gamma$-rays

In 2008, we demonstrated the existence of a HRS/IRR response in PRO cells but not in REG cells irradiated at 500 mGy.min ${ }^{-1}$. The $\mathrm{D}_{\text {HRSmax }}$ value that reflects the transition between the HRS and IRR response (i.e., the lowest survival data) was $190( \pm 8) \mathrm{mGy}$ (Thomas et al. 2008). This dose corresponds to an exposure time of $23( \pm 1) \mathrm{s}$ at $500 \mathrm{mGy} \cdot \mathrm{min}^{-1}$ (Table I). In order to examine whether doserate influences the HRS/IRR response, we investigated clonogenic survival of PRO cells irradiated at six different dose-rates between 0.0025 and $230 \mathrm{mGy} \cdot \mathrm{min}^{-1}$. For all the dose-rates applied in this study, a HRS/IRR response was systematically observed in PRO cells (Figure 1A-F). Since the distal part of the survival curves obtained at 0.3 and
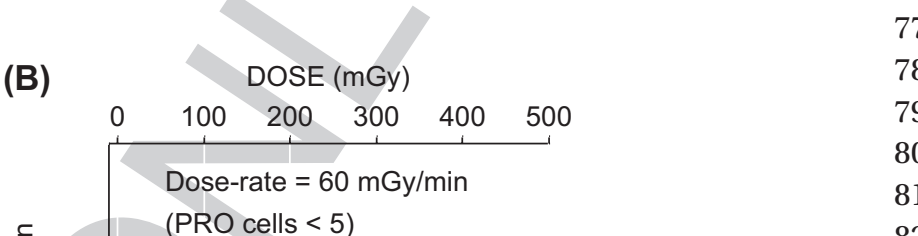

들 $($ PRO cells $<5)$

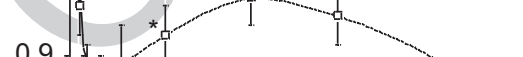
0.9 and 0.8

(D)

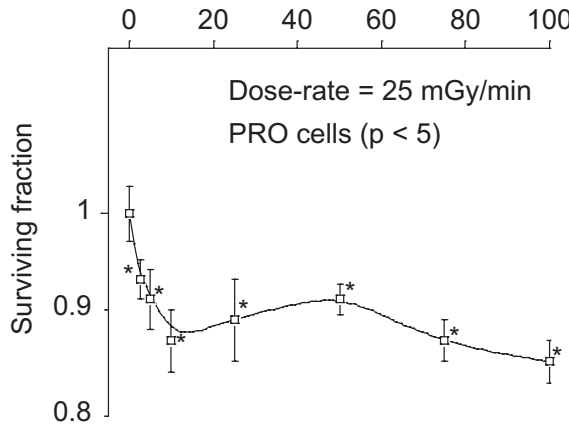

(F)

DOSE (mGy)

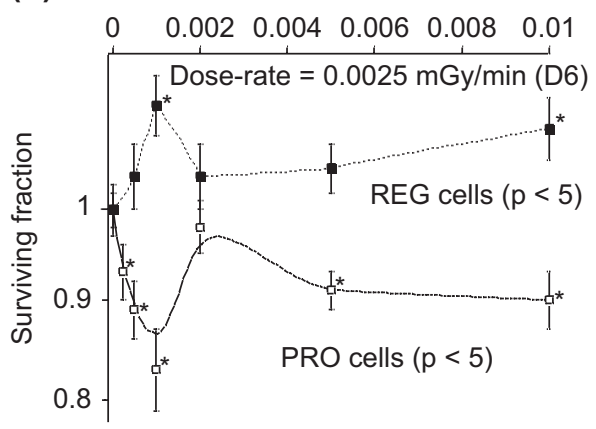

60

61

62

63

64

65

66

67

69

71

72

73

74

77 匹 11

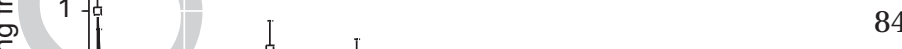

70

75

76

78

79

80

81

Figure 1. Impact of dose-rate on the HRS/IRR response. Survival curves of PRO cells (A-F) and REG cells (C and F) irradiated with cobalt $60 \gamma$-rays at low-doses. Experiments were performed with cells cultured for no more than five passages $(p<5)$. Each data represents the mean \pm SEM of three (A), three (B), two (PRO cells) and two (REG cells) (C), two (D), four (E) and three (F) experiments for cells irradiated $24 \mathrm{~h}$ after plating. Six data points per dose are included in each experiment. Figures were fitted to a smooth function. * $p<0.05$ for comparison between irradiated cells and unirradiated cells, using the $t$-test.
115

116

117 
Table III. Values of parameters obtained from the survival data fit to the IR model; $\alpha_{\mathrm{s}}$ represents the initial slope of the curve at very low doses; $\alpha_{\mathrm{r}}$ represents the low-dose slope of the survival curve extrapolated from high-doses; $d_{c}$ represents the dose that induced the change from HRS to IRR response and $\beta_{r}$ represents the distal slope of the survival curve. Numbers in parentheses are the standard errors given by the JMP software; $\mathrm{nc}=$ no convergence.

\begin{tabular}{lccccc}
\hline & $\alpha_{\mathrm{s}}$ & $\alpha_{\mathrm{r}}$ & $\alpha_{\mathrm{s}} / \alpha_{\mathrm{r}}$ & $\mathrm{d}_{\mathrm{c}}(\mathrm{mGy})$ & $\beta_{\mathrm{r}}$ \\
\hline Figure 1A & $9.96(2.1)$ & $0.43(0.23)$ & 18 & $42(8)$ & $0.124(0.5)$ \\
Figure 1B & $21.8(3.5)$ & $0.21(0.13)$ & 106 & $21(2.6)$ & $0.21(0.31)$ \\
Figure 1C (PRO cells) & $17.2(1.2)$ & $0.5(0.17)$ & 34 & $23(1.7)$ & $0.11(0.74)$ \\
Figure 1C (REG cells) & $\mathrm{nc}$ & $\mathrm{nc}$ & $\mathrm{nc}$ & $\mathrm{nc}$ & $\mathrm{nc}$ \\
Figure 1D & $31.5(1.6)$ & $1.5(0.3)$ & 21 & $11(0.7)$ & $1.22(3.45)$ \\
Figure 1E & $4.05(0.69)$ & $0.1(0.03)$ & 41 & $0.045(0.006)$ & $-0.024(0.033)$ \\
Figure 1F (PRO cells) & $0.59(0.2)$ & $0.017(0.016)$ & 35 & $0.00071(0.0002)$ & $-0.0006(0.0018)$ \\
Figure 1F (REG cells) & $\mathrm{nc}$ & $\mathrm{nc}$ & $\mathrm{nc}$ & $\mathrm{nc}$ & $\mathrm{nc}$ \\
Figure 3A (75 kV X-rays) & $55.8(5.7)$ & $1.36(1)$ & 41 & $11(1.2)$ & $4.9(10.4)$ \\
Figure 3A (60 Co $\gamma$-rays) & $31.5(1.6)$ & $1.5(0.3)$ & 21 & $11(0.7)$ & $1.22(3.45)$ \\
\hline
\end{tabular}

$0.0025 \mathrm{mGy} \cdot \mathrm{min}^{-1}$ showed negative $\beta_{\mathrm{r}}$ parameter with the IR model (Table III), all data were fitted to a smooth function (Figure 1A-F). Irrespective of the dose-rates, the HRS/IRR response was observed systematically, but not at the same dose range. For example, the lowest survival was $86 \pm 1 \%$ irrespective of dose-rate, but $\mathrm{D}_{\text {HRSmax }}$ ranged between 190 $\mathrm{mGy}$ at $500 \mathrm{mGy} \cdot \mathrm{min}^{-1}$ and $0.00071 \mathrm{mGy}$ at $0.0025 \mathrm{mGy}$. $\min ^{-1}$ (Table IV). The $\mathrm{D}_{\text {HRSmax }}$ values appeared to be a linear function of dose-rate with $\mathrm{D}_{\text {HRSmax }}=0.4428 \times$ dose-rate $\left(\mathrm{R}^{2}=0.89\right)$ (Figure $\left.2 \mathrm{~A}\right)$. The slope of this linear function corresponds to the exposure time required for the maximal HRS response. For convenience, we called it $t_{\text {HRSmax }}$. Its average value was $0.4428 \pm 0.05 \mathrm{~min}$ or $26.57 \pm 3 \mathrm{~s}$, and independent of dose-rate (Figure 2B). Similarly, if $\mathrm{D}_{\text {IRRmax }}$ and $\mathrm{t}_{\text {IRRmax }}$ are defined as the dose and the exposure time required for the maximal IRR response, respectively, our data showed that $\mathrm{D}_{\text {IRRmax }}$ is linearly dependent on dose-rate with $\mathrm{D}_{\text {IRRmax }}=0.997 \times$ dose-rate $\left(\mathrm{R}^{2}=0.99\right)$ (Figure $2 \mathrm{C}$ ). The slope $t_{\text {IRRmax }}$ was found to be $0.997 \pm 0.07$ min or $59.8 \pm 4.2 \mathrm{~s}$, and independent of dose-rate (Figure 2D). Thus, it appears that the maximal HRS and IRR responses in PRO cells correspond to exposure times that are independent of dose-rates.

Table IV. Values of the HRS/IRR response parameters obtained with PRO cells irradiated with ${ }^{60}$ Co $\gamma$-rays. $\mathrm{D}_{\mathrm{HRSmax}}$ and $\mathrm{D}_{\text {IRRmax }}$ are the doses at which the maximal HRS and IRR response are observed, respectively; $t_{H R S \max }$ and $t_{\text {IRRmax }}$ are the time at which the maximal HRS and IRR response are observed, respectively.

\begin{tabular}{|c|c|c|c|c|}
\hline $\begin{array}{l}\text { Dose-rate } \\
(\mathrm{mGy} . \\
\left.\min ^{-1}\right)\end{array}$ & $\begin{array}{c}D_{\text {HRSmax }} \\
\text { (mGy) }\end{array}$ & $\begin{array}{c}\mathrm{t}_{\text {HRSmax }} \\
(\mathrm{s})\end{array}$ & $\begin{array}{l}\mathrm{D}_{\text {IRRmax }} \\
\text { (mGy) }\end{array}$ & $\begin{array}{c}\mathrm{t}_{\text {IRRmax }} \\
(\mathrm{s})\end{array}$ \\
\hline 500 & $\begin{array}{c}190 \pm 8.1^{\mathrm{a}} \\
250^{\mathrm{b}}\end{array}$ & $\begin{array}{c}23 \pm 1^{\mathrm{a}} \\
30^{\mathrm{b}}\end{array}$ & $\begin{array}{l}500^{\mathrm{a}} \\
500^{\mathrm{b}}\end{array}$ & $\begin{array}{l}60^{\mathrm{a}} \\
60^{\mathrm{b}}\end{array}$ \\
\hline 230 & $\begin{array}{l}42 \pm 8^{\mathrm{a}} \\
37 \pm 12^{\mathrm{b}}\end{array}$ & $\begin{array}{l}11 \pm 2^{\mathrm{a}} \\
10 \pm 3^{\mathrm{b}}\end{array}$ & $\begin{array}{c}175^{\mathrm{a}} \\
217 \pm 17^{\mathrm{b}}\end{array}$ & $\begin{array}{c}46^{\mathrm{a}} \\
65 \pm 4^{\mathrm{b}}\end{array}$ \\
\hline 60 & $\begin{array}{l}21 \pm 2^{\mathrm{a}} \\
28 \pm 12^{\mathrm{b}}\end{array}$ & $\begin{array}{l}21 \pm 2^{\mathrm{a}} \\
28 \pm 12^{\mathrm{b}}\end{array}$ & $\begin{array}{c}125^{\mathrm{a}} \\
83 \pm 17^{\mathrm{b}}\end{array}$ & $\begin{array}{c}125^{\mathrm{a}} \\
83 \pm 17^{\mathrm{b}}\end{array}$ \\
\hline 44 & $\begin{array}{c}23 \pm 2^{\mathrm{a}} \\
27^{\mathrm{b}}\end{array}$ & $\begin{array}{c}31 \pm 3^{\mathrm{a}} \\
37^{\mathrm{b}}\end{array}$ & $\begin{array}{l}100^{\mathrm{a}} \\
55^{\mathrm{b}}\end{array}$ & $\begin{array}{l}136^{\mathrm{a}} \\
75^{\mathrm{b}}\end{array}$ \\
\hline 25 & $\begin{array}{c}11 \pm 1^{\mathrm{a}} \\
17^{\mathrm{b}}\end{array}$ & $\begin{array}{c}26 \pm 2^{\mathrm{b}} \\
41^{\mathrm{b}}\end{array}$ & $\begin{array}{l}50^{\mathrm{a}} \\
38^{\mathrm{b}}\end{array}$ & $\begin{array}{l}120^{\mathrm{a}} \\
91^{\mathrm{b}}\end{array}$ \\
\hline 0.3 & $\begin{array}{l}0.045 \pm 0.006^{\mathrm{a}} \\
0.031 \pm 0.006^{\mathrm{b}}\end{array}$ & $\begin{array}{l}9 \pm 1^{a} \\
6 \pm 1^{b}\end{array}$ & $\begin{array}{c}0.2^{\mathrm{a}} \\
0.19 \pm 0.1^{\mathrm{b}}\end{array}$ & $\begin{array}{c}40^{\mathrm{a}} \\
38 \pm 20^{\mathrm{b}}\end{array}$ \\
\hline 0.0025 & $\begin{aligned} 0.00071 & \pm 0.0002^{\mathrm{a}} \\
0.0005 & \pm 0.00025^{\mathrm{b}}\end{aligned}$ & $\begin{array}{l}17 \pm 5^{\mathrm{a}} \\
12 \pm 6^{\mathrm{b}}\end{array}$ & $\begin{array}{c}0.004^{\mathrm{a}} \\
0.002 \pm 0.0009^{\mathrm{b}}\end{array}$ & $\begin{array}{c}96^{\mathrm{a}} \\
48 \pm 22^{\mathrm{b}}\end{array}$ \\
\hline
\end{tabular}

aParameters obtained from survival data fit to the IR model. ${ }^{\text {bexperimental }}$ parameters obtained from raw survival data shown in Figure 1 except those at 500 mGy. $\mathrm{min}^{-1}$ (taken from Thomas et al. 2008).
In agreement with our previous data obtained at 500 mGy. $\min ^{-1}$, it is noteworthy that REG cells did not show marked HRS/IRR response at $44 \mathrm{mGy} \cdot \mathrm{min}^{-1}$ and 0.0025 mGy. $\min ^{-1}$ (Figure 1C and 1F, respectively). Conversely, REG cells displayed significant radio-stimulation at 0.0025 mGy. $\mathrm{min}^{-1}$ (Figure $1 \mathrm{~F}$ ). Such very low dose-rate is known to stimulate the division potential in normal cells (e.g., Croute et al. 1986, Planel et al. 1987). However, these hormetic-like responses and their possible cellular mechanisms - that were recently reviewed (Szumiel 2012) - are beyond the scope of this paper (Supplementary Material to be found online at http://informahealthcare.com/abs/doi/10.3109/ 09553002.2013.800248).

\section{Comparison with the literature}

We reviewed the HRS/IRR responses obtained in the literature from 1993-2012 (Table I). As a first step, only low-LET radiation ( $\mathrm{X}$ - and $\gamma$-rays) data obtained at single dose-rate with short exposure times less than 10 min were considered. With regard to the HRS/IRR response parameters, no significant difference was observed between human and rodent cells. By pooling rodent and human data shown in Table I, the HRS/IRR responses were obtained at an average doserate of $1000 \mathrm{mGy} \cdot \mathrm{min}^{-1}$. At such dose-rate, the $\mathrm{D}_{\text {HRSmax }}$ and $\mathrm{D}_{\text {IRRmax }}$ values obtained in the literature are in agreement with our data (Figure $1 \mathrm{~A}$ and $\mathrm{C}$ ). The $\mathrm{t}_{\mathrm{HRSmax}}$ value obtained in the literature [23 $\pm 4 \mathrm{~s}$ (mean \pm SEM, $n=25)]$ was not significantly different from the experimental $\mathrm{t}_{\mathrm{HRSmax}}$ value obtained in this study [23.4 $\pm 5.3 \mathrm{~s}$ (mean \pm SEM, $n=7$ )] (Table IV). Similarly, the $\mathrm{t}_{\text {IRRmax }}$ value obtained in the literature $[59 \pm 12 \mathrm{~s}($ mean $\pm \mathrm{SEM}, n=25)]$ was not significantly different from the experimental $t_{\text {IRRmax }}$ value obtained in this study [66 $\pm 7.1 \mathrm{~s}$ (mean $\pm \mathrm{SEM}, n=7)]$ (Table IV). By pooling literature and our data, over a very large range of dose-rates $\left(0.0025-2430 \mathrm{mGy} \cdot \mathrm{min}^{-1}\right) \mathrm{t}_{\text {HRSmax }}$ and $\mathrm{t}_{\mathrm{IRR} \max }$ were found to be $23 \pm 3 \mathrm{~s}$ and $60 \pm 9 \mathrm{~s}[$ mean $\pm \operatorname{SEM}(n=32)]$, respectively.

\section{HRS/IRR response of PRO cells irradiated with $75 \mathrm{kV} X$-rays}

Since radiodiagnosis exams like computed tomography (CT) scans involve low-energy X-rays rather than high-energy $\gamma$-rays, we examined whether the HRS/IRR response of PRO cells also exists with $75 \mathrm{kV}$ X-rays. With regard to dose-rate, we chose to work at $25 \mathrm{mGy} \cdot \mathrm{min}^{-1}$ since this dose-rate 

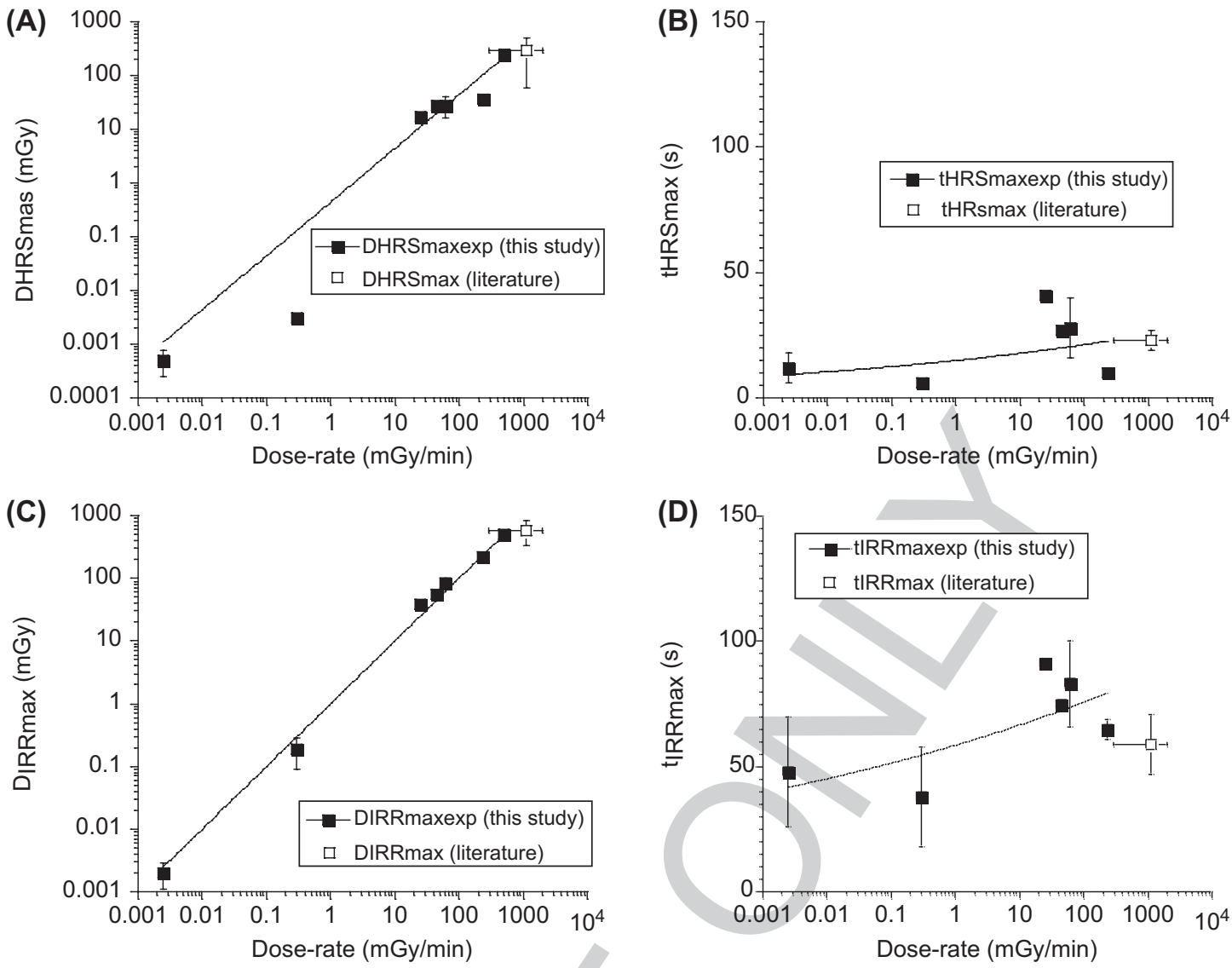

Figure 2. Relationships between the HRS/IRR response experimental parameters (shown in Table IV) and the dose-rates in PRO cells. (A) Significant linear correlation between $\mathrm{D}_{\text {HRSmax }}$ and dose-rate was found $\left(\mathrm{y}=0.4428 . \mathrm{x}, \mathrm{R}^{2}=0.89, p<0.05\right)$. (B) $\mathrm{t}_{\mathrm{HRSmax}}$ was not significantly correlated to dose-rate. (C) Significant linear correlation between $\mathrm{D}_{\text {IRRmax }}$ and dose-rate was found ( $\left.\mathrm{y}=0.997 . \mathrm{x}, \mathrm{R}^{2}=0.99, p<0.05\right)$. (D) $\mathrm{t}_{\mathrm{IRRmax}}$ was not significantly correlated to dose-rate. Error bars indicate the SEM for $n=2-4$ independent experiments taken from Figures $1 \mathrm{~A}-\mathrm{F}(\boldsymbol{\square})$ and for 25 independent experiments obtained with low-LET radiation taken from Table I ( $\square)$.

generally applied in CT scan exams. Figure 3A shows that in the 5-100 mGy range, the HRS/IRR response occurs in PRO cells. Although the extent of the HRS response in PRO cells appeared to be larger with $75 \mathrm{kVX}$-rays than with ${ }^{60} \mathrm{Co} \gamma$-rays, the survival data were not found significantly different (Figure 3A). Accordingly, the HRS and the IRR response parameters fitted with the IR model were found similar with $75 \mathrm{kV}$ $\mathrm{X}$-rays and ${ }^{60} \mathrm{Co} \gamma$-rays (Table III). Finally we confirmed that REG cells irradiated with $75 \mathrm{kV}$ X-rays did not display significant HRS/IRR response (data not shown).

\section{DSB repair features of HRS/IRR response}

Thereafter, by using $75 \mathrm{kV}$ X-rays delivered at $25 \mathrm{mGy}$. $\mathrm{min}^{-1}$, we examined the radiation-induced DSB reflected by $\gamma$-H2AX foci in two representative conditions: After $10 \mathrm{mGy}$, corresponding to the maximal HRS response $\left(\mathrm{D}_{\text {HRSmax }}\right)$ and an exposure time lower than $\mathrm{t}_{\mathrm{HRSmax}}$; after $100 \mathrm{mGy}$, corresponding to dose higher than the maximal IRR response (doses higher than $\mathrm{D}_{\text {IRRmax }}$ ) and exposure time longer than $\mathrm{t}_{\text {IRRmax }}$. Figure 3B showed that for both doses, the kinetics of appearance/disappearance of $\gamma-\mathrm{H} 2 \mathrm{AX}$ foci elicited the same biphasic shape: (i) An increase of the number of $\gamma$-H2AX foci corresponding to the recognition of radiation-induced DSB managed by NHEJ; (ii) a decrease of the number of $\gamma-\mathrm{H} 2 \mathrm{AX}$ foci corresponding to the repair of recognized DSB. However, while the maximal number of $\gamma-\mathrm{H} 2 \mathrm{AX}$ foci ranged from 7-11 nuclear foci for both doses, the incubation times at which it was reached differed significantly, i.e., $4 \mathrm{~h}$ and $1 \mathrm{~h}$ post-irradiation after a dose of $10 \mathrm{mGy}$ and $100 \mathrm{mGy}$, respectively. Furthermore, while the DSB repair is completed after $100 \mathrm{mGy}$, the DSB induced by $10 \mathrm{mGy}$ appeared to be more severe with $5.5 \pm 0.7$ residual $\gamma$-H2AX foci $24 \mathrm{~h}$ after irradiation (Figure 3B). These data suggest that $\mathrm{t}_{\text {HRSmax }}$ may be associated with deficient NHEJ repair and maximal HRS response while $t_{\text {IRRmax }}$ may be associated with full NHEJ repair and maximal IRR response.

\section{Discussion}

\section{Impact of dose-rate on the HRS/IRR response}

By investigating one of the largest ranges of dose-rates applied in HRS/IRR studies, our data show that the maximal HRS and IRR responses obtained with low-LET radiation correspond to exposure times of about $20 \mathrm{~s}$ and $60 \mathrm{~s}$, respectively. To our knowledge, the impact of dose-rate and exposure time on the HRS/IRR response have not been investigated per se, notably with short exposure times less than $10 \mathrm{~min}$. Exposure time is basically dependent on dose and dose-rate since these three parameters are linked mathematically. The dose-rates applied in the published studies ranging from 0.18-2.43 Gy. $\mathrm{min}^{-1}$ (Table I), have rarely been explained: Their choice generally results from 

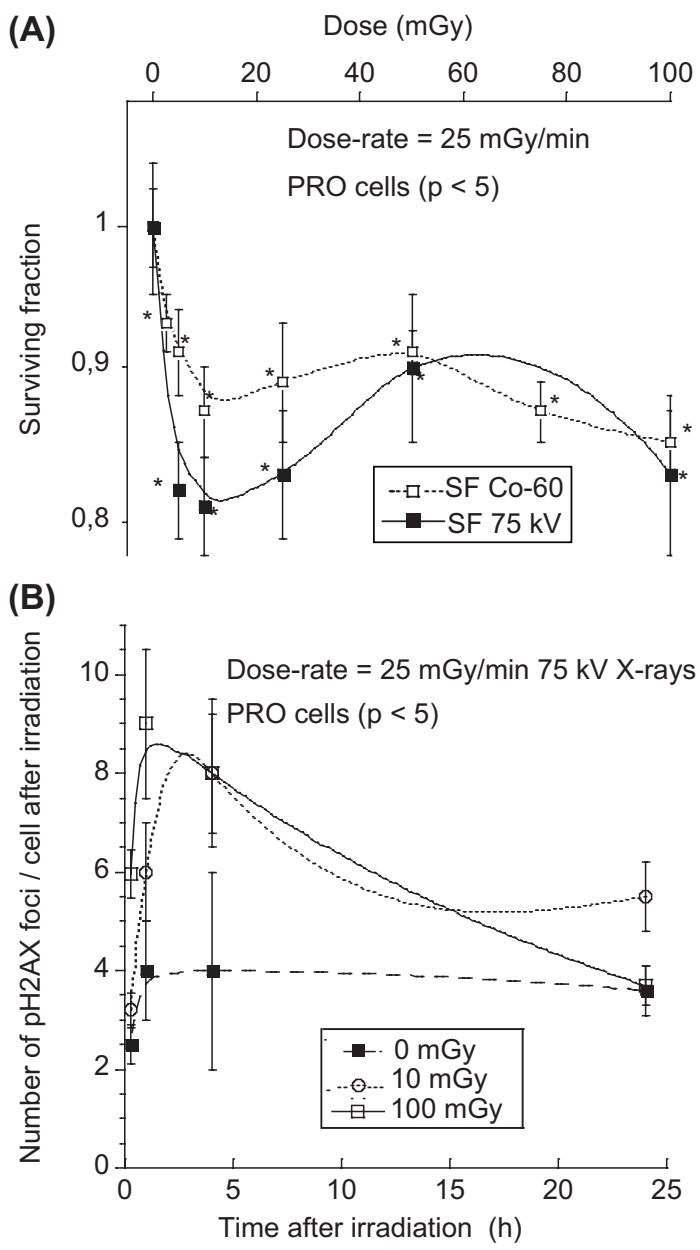

Figure 3. HRS/IRR response of PRO cells irradiated with $75 \mathrm{kV}$ X-rays. (A) Comparison between ${ }^{60} \mathrm{Co} \gamma$-rays survival data (dashed line) and $75 \mathrm{kV}$ X-rays survival data (continuous line). Experiments were performed with cells cultured for no more than 5 passages. Each data represents the mean \pm SEM of two independent experiments for cells irradiated $24 \mathrm{~h}$ after plating. Six data points per dose are included in each experiment. ${ }^{*} p<0.05$ for comparison between unirradiated cells and irradiated cells using the $t$-test. (B) Kinetic of DSB repair at $10 \mathrm{mGy}$ (HRS response) or $100 \mathrm{mGy}$ (IRR response). Each data represent the mean \pm SEM of 3-5 independent experiments for cells irradiated $24 \mathrm{~h}$ after plating. All data in Figure 3 were fitted to a smooth function.

a practical compromise between the availabilities of the irradiator in the laboratory, a short exposure time to avoid artifacts and the possibility to expose cells during a minimal time. For example, some authors used several dose-rates for completing a single survival curve (e.g., Marples and Joiner 1993, Martin et al. 2009). We deliberately chose not to include the studies using several dose-rates in our review shown in Table I. Similarly, HRS/IRR responses obtained with long exposure times (generally longer than $1 \mathrm{~h}$ ) were not considered (e.g., Enns et al. 2004).

Some HRS/IRR responses were also observed with other radiation than $\mathrm{X}$ - or $\gamma$-rays. This is notably the case of neutrons (Dionnet et al. 2000), $\alpha$-rays (Tsoulou et al. 2001), protons (Petrovic et al. 2010), heavy ions (Xue et al. 2009) and $\beta$-rays (Wéra et al. 2012). Interestingly, $D_{\text {HRSmax' }}$ $\mathrm{D}_{\text {IRRmax }}, \mathrm{t}_{\text {HRSmax }}, \mathrm{t}_{\text {IRRmax }}$ are also in agreement with the values range of our review (Table I), which consolidates our conclusions showing that the maximal HRS and IRR responses would correspond, (by pooling literature and our data), to average exposure times of $31 \pm 8$ s (SEM, $n=35$ ) and $58 \pm 9 \mathrm{~s}$ (SEM, $n=35$ ), respectively, irrespective of the radiation type (low and high-LET radiation). Thus our data suggest that the HRS response is not limited to low-doses since $t_{\text {HRSmax }}$ can theoretically be reached with high-doses. Accordingly, tumor cells irradiated at $2 \mathrm{~Gy}$ with protons at 15 Gy. $\min ^{-1}$ (exposure time $=8 \mathrm{~s}$ ) showed HRS response (Petrovic et al. 2010). However, since most HRS/IRR responses were obtained with low-LET radiation corresponding to cell survival of $75 \pm 18 \%$ (mean \pm SD, $n=28$ ) with doses ranging from 100-800 mGy (Table I), we stressed that the validity of the HRS/IRR response may not be relevant for higher doses and lower cell survival.

\section{Biological significance of $t_{\text {HRSmax }}$}

The findings that $\mathrm{t}_{\text {HRSmax }}$ and $\mathrm{t}_{\text {IRRmax }}$ are constant and common to human and rodent cells, tumor and transformed normal cells suggest that exposure times corresponding to the maximal HRS and IRR responses may not entirely depend on cellular parameters like cellular model or cell death pathways. Furthermore, a drastic decrease of cell survival was shown to be correlated with DSB repair impairments with a number of cellular models and conditions (e.g., Joubert et al. 2008). In mammalian cells, DSB are mainly recognized and repaired by the NHEJ pathway. Particularly, alterations in NHEJ induce hyper-radiosensitivity at high-doses. This is the case of ATM-, ligase (LIG) 4-, DNAprotein kinase (PK)-mutated cell lines that exhibit a survival fraction at 2 Gy (SF2) of about 1\% (Joubert et al. 2008). Interestingly, the $\alpha$ parameter of the LQ model and the surviving fractions corresponding to these hyperradiosensitive cell lines are very similar to those observed in the initial part of the survival curve in PRO cells and in other HRS-positive cell lines sorted in Table I. We suggest therefore that the $\left[0-t_{\text {HRSmax }}\right]$ exposure time interval may correspond to an incapacity of NHEJ to recognize and repair efficiently the induced DSB, as it is the case for the ATM-, LIG4-, DNA-PK-mutated cells. It was shown that the ATM kinase produces a cascade of phosphorylations of proteins involved in the radiation response (Foray et al. 2003). The NHEJ repair pathway requires several steps such as: (i) DSB recognition, (ii) interaction between ATM and $\gamma$-H2AX, and (iii) complete H2AX phosphorylation. In our hands, at least $10 \mathrm{~min}$ post-irradiation are required to observe the maximal number of $\gamma$-H2AX foci. Besides, some authors applied $30 \mathrm{~min}$ post-irradiation to assess the number of recognized DSB (e.g., Joubert et al., 2008). Hence, DSB recognition and repair steps likely require much more than $20 \mathrm{~s}$. Since residual DSB is observed $24 \mathrm{~h}$ after irradiation at $10 \mathrm{mGy}$ delivered either at $25 \mathrm{mGy} \cdot \mathrm{min}^{-1}$ (exposure time of $24 \mathrm{~s}$ ) (this study) or at $70 \mathrm{mGy} \cdot \mathrm{min}^{-1}$ (exposure time $8.5 \mathrm{~s}$ ) (Grudzenski et al. 2010), we suggest that $t_{\text {HRSmax }}$ may be consistent with the time corresponding to deficient NHEJ repair.

\section{Biological significance of $t_{\text {IRRmax }}$}

With regard to the second part of the survival curve ranging from $t_{\text {HRSmax }}$ to $t_{\text {IRRmax }}$, an increase of cell survival is observed: induced-radioresistance (IRR) is the major interpretation of this part of the survival curve (Krueger et al. 2007b). 
The $t_{\text {IRRmax }}$ exposure time would therefore correspond to the time necessary for a fully active NHEJ pathway. Our data in Figure 3B show that NHEJ repair is complete $24 \mathrm{~h}$ after irradiation at $100 \mathrm{mGy}$ delivered at $25 \mathrm{mGy} \cdot \mathrm{min}^{-1}$ which corresponds to an exposure time larger than $\mathrm{t}_{\text {IRRmax }}$. Accordingly, $t_{\text {IRRmax }}$ may be compatible with kinetic of change in chromatin structure and nucleo-shuttling of pATM forms (Bakkenist and Kastan 2003), the earliest time to detect $\gamma$-H2AX foci after irradiation (Rothkamm and Löbrich 2003) and the time required for induced repair after low-dose X-rays [e.g., $68 \mathrm{~s}$ or $80 \mathrm{mGy}$ delivered at $70 \mathrm{mGy} \cdot \mathrm{min}^{-1}$
(Grudzenski et al. 2010)]. Altogether, our data are compatible with three exposure time phases and N-shaped doseresponse curve regarding DSB and cell survival (Figure 4):

- $\quad \mathrm{t}<\mathrm{t}_{\mathrm{HRSmax}}$ : Incomplete DSB recognition by NHEJ and decrease of cell survival (HRS response);

- $\quad \mathrm{t}_{\text {HRSmax }}<\mathrm{t}<\mathrm{t}_{\text {IRRmax }}$ : Progressive activation of NHEJ and increase of cell survival (IRR response);

- $\quad t>\mathrm{t}_{\text {IRRmax }}$ : All DSB are recognized but they are so numerous that they cannot be all repaired; decrease of cell survival (beyond the HRS/IRR response).

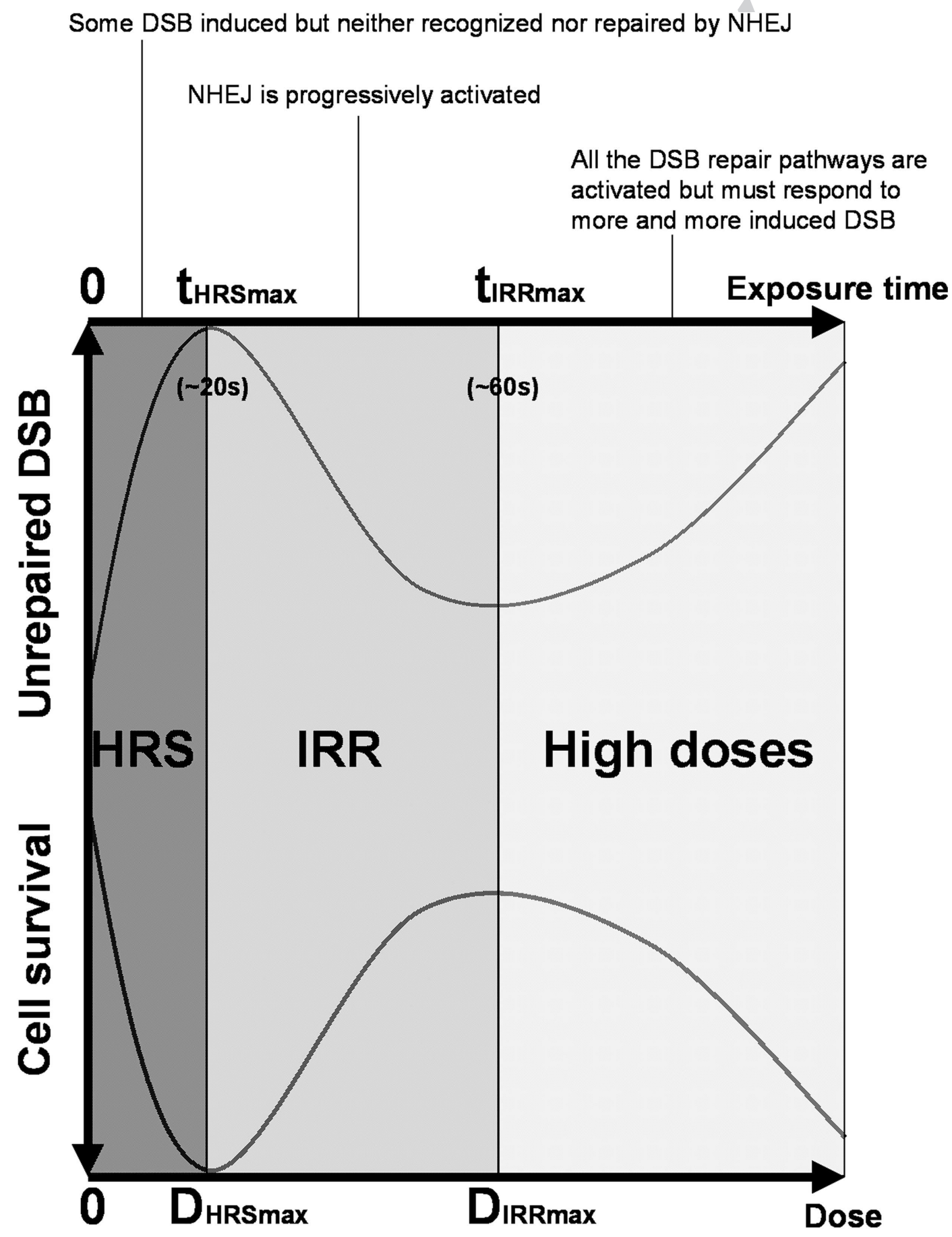

Figure 4. Model for the HRS/IRR response. From 0 to $\mathrm{D}_{\text {HRSmax }}$, radiations induce physical DSB that are not all recognized biologically and therefore unrepaired. Consequently, cell survival decreases. From $D_{\text {HRSmax }}$ to $D_{\text {IRRmax }}$ DSB are all recognized biologically and progressively repaired and cell survival increases. For doses higher than $\mathrm{D}_{\mathrm{IRRmax}}$ DSB are all recognized but their amount is so large that some DSB are not repaired and cell survival decreases. 


\section{Potential impact of the HRS/IRR response in radiotherapy}

Our findings suggest that significant decrease of cell survival could be reached independently of dose-rate provided that exposure times are shorter than $30 \mathrm{~s}$. This may be notably the case of the cyberknife ${ }^{\mathrm{TM}}$ radiotherapy technique that delivers non-uniform patterns of intermittent radiation using a compact miniaturized $6 \mathrm{MV}$ nominal linear accelerator with high doses-rates of 4,6 or $8 \mathrm{~Gy} \cdot \mathrm{min}^{-1}$. The dose per fraction is delivered using 80-150 non-coplanar sequential mini-beams with $<0.1 \%$ leakage at $1 \mathrm{~m}$ from the beam path. For example, for a dose per fraction of about 7 Gy to the brain, the peripheral dose is less than $5 \mathrm{mGy}$ at $80 \mathrm{~cm}$ from the target (Di Betta et al. 2010). Interestingly, cyberknife delivers a single fraction of the total dose in 1-36 s with an interval between two beams of 5 s (Murphy et al. 2007). Furthermore, Lin and $\mathrm{Wu}$ reported that not all 2 Gy fractions are equivalent: Human and rodent cells irradiated with ${ }^{60} \mathrm{Co} \gamma$-rays at $1.3-1.5$ Gy. $\mathrm{min}^{-1}$ in 10 fractions of $0.2 \mathrm{~Gy}$ (corresponding to about $8 \mathrm{~s}$ per fraction with an interval of $16 \mathrm{~s}$ between fractions) showed higher radiosensitivity than a single fraction of $2 \mathrm{~Gy}$ (corresponding to an exposure time of $86 \mathrm{~s}$ at $1.4 \mathrm{~Gy} \cdot \mathrm{min}^{-1}$ ) (Lin and Wu 2005). Thus data suggest that intermittent irradiation delivered in multiple fractions or continuous irradiation delivered in a single fraction with exposure time per fraction shorter than $20 \mathrm{~s}$ may show maximal HRS response independently of dose-rate. However, further investigations are required to examine whether the time between fractions impacts significantly on the HRS response.

Finally and consistently with our previous reports (Thomas et al. 1997, 2001, 2007, 2008), we suggest that the HRS response may be relevant to target unvascularized micrometastases with peripheral doses received at a distance from the clinical target volume irradiated with intermittent radiation. In the context of oligometastatic disease, local ablative stereotactic irradiation can be used to eradicate gross tumor while the potential microscopic disease is managed using systemic treatments (chemotherapy) or left untreated (Thariat et al. 2012). We suggest that the HRS response driven by short exposure times such as used with stereotactic radiotherapy may find also application to manage micrometastatic disease at distance from the irradiated gross tumor. More experimental and clinical investigations with additional highly metastatic human cell lines will be needed to verify this medical hypothesis.

\section{Acknowledgements}

We are grateful to the reviewers for their helpful comments and to Dr Christian Mazars and his team [Unité Mixte de Recherche (UMR) Université Paul Sabatier (UPS)-Centre National de la Recherche Scientifique (CNRS) 5546, Toulouse] for helpful discussions. We thank also Madame Beaufrère for her assistance in editing English.

\section{Declaration of interest}

The authors report no conflicts of interest. The authors alone are responsible for the content and writing of the paper.
This work is supported by the Alliance de la Vie et de la Santé (AVIESAN), the Agence Nationale de la Recherche (ANR), the Institut National du Cancer (INCa), the Centre National d'Etudes Spatiales (CNES) and the Association pour la Recherche sur l'ataxie Telangiectasie (APRAT).

\section{References}

Barkowiak D, Högner S, Nothdurft W, Röttinger EM. 2001. Cell cycle and growth response of cHO cells to X-irradiation: Threshold-free repair at low-doses. International Journal of Radiation Oncology Biology Physics 50:221-227.

Beauchesne P, Bertrand S, Branche R, Linke SP, Doré JF, Pedeux RM. 2003. Human malignant glioma cell lines are sensitive to low radiation doses. International Journal of Cancer 105:33-40.

Bakkenist CJ, Kastan MB. 2003. DNA damage activates ATM through intermolecular autophosphorylation and dimmer dissociation. Nature 421:499-506.

Chandna S, Dwarakanath BS, Khaitan D, Mathew TL, Jain V. 2002. Lowdose radiation hypersensitivity in human tumour cell lines: Effects of cell-cell contact and nutritional deprivation. Radiation Research 157:516-525.

Croute F, Vidal S, Soleilhavoud JP, Vincent C, Serre G, Planel H. 1986. Effects of a very low dose rate of chronic ionizing radiation on the division potential of human embryonic lung fibroblasts in vitro. Experimental Gerontology 21:1-11.

Di Betta E, Fariselli L, Bergantin A, Locatelli F, Del Vecchio A, Broggi S, Fumagalli ML. 2010. Evaluation of the peripheral dose in stereotactic radiotherapy and radiosurgery treatments. Medical Physics 137:3587-3594.

Dionnet C, Tchirkov A, Alard JP, Arnold J, Dhermain J, Rapp M, Bodez V, Tamain JC, Monbel I, Malet P, Kwiatkowski F, Donnarieix D, Veyre A, Verelle P. 2000. Effects of low-dose neutrons applied at reduced dose rate on human melanoma cells. Radiation Research 154:406-411.

Edin NJ, Olsen DR, Stokke T, Pettersen EO. 2007. Recovery of low-dose hyper-radiosensitivity following a small priming dose depends on priming dose-rate. International Journal of Low Radiation 4:69-86.

Enns L, Bogen KT, Wizniak J, Murtha AD, Weinfeld M. 2004. Lowdose radiation hypersensitivity is associated with p53-dependent apoptosis. Molecular Cancer Research 2:557-566.

Foray N, Marot D, Gabriel A, Randrianarison V, Carr AM, Perricaudet M, Ashworth A, Jeggo P. 2003. A subset of ATM- and ATR-dependent phosphorylation events requires the BRCA1 protein. EMBO Journal 22:2860-2871.

Grudzenski S, Raths A, Conrad S, Rübe CUE, Löbrich M. 2010. Inducible response required for repair of low-dose radiation damage in human fibroblasts. Proceedings of the National Academy of Sciences of the USA 107:14205-14210.

Joiner MC, Denekamp J, Maughan RL. 1986. The use of 'top-up' experiments to investigate the effect of very small doses per fraction in mouse skin. International Journal of Radiation Biology 49: 565-580.

Joiner MC, Marples B, Lambin P, Short SC, Turesson I. 2001. Lowdose hypersensitivity: Current status and possible mechanisms. International Journal of Radiation Oncology Biology Physics 49: 379-389.

Joubert A, Zimmerman KM, Bencokova, Z, Gastaldo J, Rénier W, Chavaudra N, Favaudon V, Arlett CF, Foray N. 2008. DNA doublestrand break repair defect in syndromes associated with acute radiation response: Involvement of DNA-PK-and MRE11-dependent pathways. International Journal of Radiation Biology 84:107-125.

Krueger SA, Joiner MC, Weinfeld M, Piasentin E, Marples B. 2007a. Role of apoptosis in low-dose hyper-radiosensitivity. Radiation Research 167:260-267.

Krueger SA, Collis SJ, Joiner MC, Wilson GD, Marples B. 2007b. Transition in survival from low-dose hyper-radiosensitivity to increased radioresistance is independent of activation of ATM SER1981 activity. International Journal of Radiation Oncology Biology Physics 69:1262-1271.

Lambin P, Marples B, Fertil B, Malaise, EP, Joiner MC. 1993. Hypersensitivity of a human tumour cell line to very low radiation doses. International Journal of Radiation Biology 63:639-650.

Lambin P, Malaise EP, Joiner MC. 1996. Might intrinsic radioresistance of human tumour cells be induced by radiation? International Journal of Radiation Biology 69:279-290. 
Lin PS, Wu A. 2005. Not all 2 Gray radiation prescriptions are equivalent: Cytotoxic effect depends on delivery sequences of partial fractionated doses. International Journal of Radiation Oncology Biology Physics 63:536-544.

Marples B, Joiner MC. 1993. The response of Chinese Hamster V79 cells to low radiation doses: Evidence of enhanced sensitivity of the whole cell population. Radiation Research 133:41-51.

Marples B, Wouters BG, Collis SJ, Chalmers AJ, Joiner MC. 2004. Lowdose hyper-radiosensitivity: A consequence of ineffective cell cycle arrest of radiation-damaged G2-phase cells. Radiation Research 161:247-255.

Marples B, Collis SJ. 2008. Low-dose hyper-radiosensitivity: Past, present and future. International Journal of Radiation Oncology Biology Physics 70:1310-1318.

Martin F, Caignard A, Jeannin JF, Leclerc A, Martin M. 1983. Selection by trypsin of two sublines of rat colon cancer cells forming progressive or regressive tumours. International Journal of Cancer 32:623-627.

Martin L, Marples B, Coffey M, Lawler, Hollywood D, Marignol L. 2009. Recognition of O6MeG lesions by MGMT and mismatch repair proficiency may be a prerequisite for low-dose radiation hypersensitivity. Radiation Research 172:405-413.

Mothersill C, Harney J, Lyng F, Cotell D, Parsons, Murphy DM, Seymour CB. 1995. Primary explants of human uroepithelium show an usual response to low-dose irradiation with cobalt-60 gamma rays. Radiation Research 142:181-187.

Murphy MJ, Lin PS, Ozhasoglu C. 2007. Intra-fraction dose delivery timing during stereotactic radiotherapy can influence the radiobiological effect. Medical Physics 34:481-484.

Nuta O, Darroudi F. 2008. The impact of the bystander effect on the low-dose hypersensitivity phenomenon. Radiation Environment Biophysics 47:265-274.

Petrovic I, Ristic-Fira A, Todorovic D, Koricanac L, Valastro L, Cirrone P, Cuttone G. 2010. Response of a radioresistant human melanoma cell line along the proton spread-out Bragg peak. International Journal of Radiation Biology 86:742-751.

Planel H, Soleilhavoud JP, Tixador R, Richoilley G, Conter A, Croute F, Caratero C et al. 1987. Influence on cell proliferation of background radiation or exposure to very low, chronic $\gamma$ radiation. Health Physics 52:571-578.

Rothkamm K, Löbrich M. 2003. Evidence for a lack of DNA doublestrand break repair in human cells exposed to very low X-ray doses. Proceedings of the National Academy of Sciences of the USA 100:5057-5062.

Slonina D, Biesaga B, Urbanski K, Kojs Z. 2007. Low-dose radiation response of primary keratinocytes and fibroblasts from patients with cervix cancer. Radiation Research 167:251-259.

\section{Supplementary material available online}

Survival fraction data for PRO cells irradiated at $230 \mathrm{mGy} / \mathrm{min}$ (D1), $60 \mathrm{mGy} / \mathrm{min}$ (D2), $44 \mathrm{mGy} / \mathrm{min}$ (D3), $25 \mathrm{mGy} / \mathrm{min}$ (D4), $0.3 \mathrm{mGy} / \mathrm{min}$ (D5) and $0.0025 \mathrm{mGy} / \mathrm{min}$ (D6); survival data for REG cells irradiated at $44 \mathrm{mGy} / \mathrm{min}$ (D3) and $0.0025 \mathrm{~Gy} / \mathrm{min}$ (D6).
Short SC, Bourne S, Martindale C, Woodcock M, Jackson SP. 2005. DNA damage responses at low radiation doses. Radiation Research 164:292-302.

Szumiel I. 2012. Radiation hormesis: Autophagy and other cellular mechanisms. International Journal of Radiation Biology 88: 629-628.

Thariat J, Vignot S, Bensadoun RJ, Mornex F. 2012. Improvements of ablative local treatments modify the management of the oligometastatic disease. Cancer Radiotherapy 16:325-329.

Thomas C, Buronfosse A, Portoukalian J, Fertil B. 1997. The gangliosides as a molecular coupling factor between the proportion of radiosensitive cells in vitro and the metastatic potential in vivo within a human melanoma cell line. British Journal of Cancer 75:639-649.

Thomas C, Buronfosse A, Courdi A, Fertil B. 2001. Radio-prevention of micrometastasis. Medical Hypothesis 57:398-404.

Thomas C, Fertil B, Foray N. 2007. Very low-dose hyper-radiosensitivity: Impact for radiotherapy of micrometastases. Cancer Radiotherapy 11:260-265.

Thomas C, Charrier J, Massart C, Cherel M, Fertil B, Barbet J, Foray N. 2008. Low-dose hyper-radiosensitivity of progressive and regressive cells isolated from a rat colon tumour: Impact of DNA repair. International Journal of Radiation Biology 84:533-548.

Tsoulou E, Baggio L, Cherubini, Kalfas CA. 2001. Low-dose hypersensitivity of V79 cells under exposure to $4 \mathrm{He}$ ions of differen energies: Survival and chromosome aberrations. International Journal of Radiation Biology 77:1133-1139.

Vaganay-Juery S, Muller C, Marangoni B, Abdulkarim B, Deutsch E, Lambin P, Calsou P, Eschwege F, Salles B, Joiner MC, Bourhis J. 2000. Decreased DNA-PK activity in human cancer cells exhibiting hypersensitivity to low-dose irradiation. British Journal of Cancer 83:514-518.

Wéra AC, Borlon C, Nuttens VE, Riquier H, Feron O, Michiels C, Lucas S. 2012. Comparison of the clonogenic survival of A549 non-small cell lung adenocarcinoma cells after irradiation with lowdose-rate beta particles and high-dose-rate X-rays. International Journal of Radiation Biology 88:253-257.

Wykes SM, Piasentin E, Joiner MC, Wilson GD, Marples B. 2006. Low-dose hyper-radiosensitivity is not caused by a failure to recognize DNA double-strand breaks. Radiation Research 165: 516-524.

Xue L, Yu D, Furusawa Y, Cao J, Okayasu R, Fan S. 2009. ATP-dependent hyper-radiosensitivity in mammalian cells irradiated by heavy ions. International Journal of Radiation Oncology Biology Physics 75: 235-243.
60

61

62

63

64

65

66

67

68

69 
Supplementary material for Thomas C, et al. Impact of dose-rate on the low-dose hyper-radiosensitivity and induced 60 radioresistance (HRS/IRR) response. International Journal of Radiation Biology, 2013; doi: 10.3109/09553002.2013.800248.

PRO cells D1.

\begin{tabular}{|c|c|c|c|c|c|c|}
\hline Control & $10 \mathrm{mGy}$ & $25 \mathrm{mGy}$ & $50 \mathrm{mGy}$ & $100 \mathrm{mGy}$ & $250 \mathrm{mGy}$ & $500 \mathrm{mGy}$ \\
\hline 1.18 & 1.02 & 0.89 & 0.98 & 0.93 & 0.8 & 0.8 \\
\hline
\end{tabular}

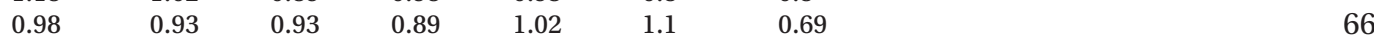

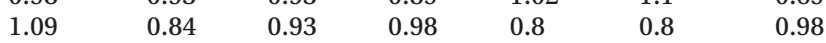

$\begin{array}{lllllll}0.98 & 0.93 & 0.89 & 0.84 & 0.98 & 1.05 & 0.8\end{array}$

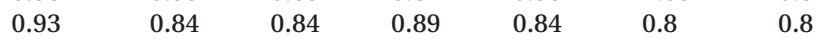

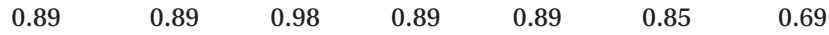

$\begin{array}{lllllll}0.98 & 0.8 & 1 & 0.9 & 0.6 & 0.98 & 0.75\end{array}$

$\begin{array}{lllllll}0.93 & 0.6 & 0.9 & 0.8 & 0.8 & 0.91 & 0.7\end{array}$

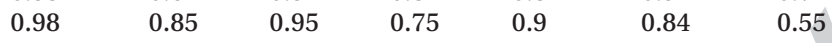

$\begin{array}{lllllll}1.13 & 0.9 & 0.7 & 0.8 & 1 & 0.84 & 0.75\end{array}$

$\begin{array}{lllllll}1.09 & 0.85 & 0.65 & 0.75 & 0.9 & 0.77 & 0.75\end{array}$

$\begin{array}{lllllll}0.93 & 0.75 & 0.95 & 0.6 & 0.95 & 0.91 & 0.5\end{array}$

$\begin{array}{llllll}1 & 0.95 & 0.84 & 0.84 & 0.84 & 0.88\end{array}$

$\begin{array}{llllll}1 & 1.09 & 1.05 & 0.91 & 0.77 & 0.95\end{array}$

$\begin{array}{llllll}1.2 & 0.81 & 0.88 & 0.91 & 0.81 & 0.7\end{array}$

$\begin{array}{llllll}0.8 & 0.84 & 0.84 & 0.91 & 0.84 & 0.77\end{array}$

$\begin{array}{llllll}1.1 & 0.98 & 0.98 & 0.95 & 0.84 & 0.98\end{array}$

$\begin{array}{llllll}0.9 & 0.91 & 0.91 & 0.91 & 0.84 & 0.98\end{array}$

1.12

1.09

0.91

0.91

0.84

PRO cells D2.

\begin{tabular}{lccccccccc}
\hline Control & $1 \mathrm{mGy}$ & $5 \mathrm{mGy}$ & $10 \mathrm{mGy}$ & $25 \mathrm{mGy}$ & $50 \mathrm{mGy}$ & $100 \mathrm{mGy}$ & $200 \mathrm{mGy}$ & $300 \mathrm{mGy}$ & $500 \mathrm{mGy}$ \\
\hline 0.91 & 0.94 & 0.75 & 0.84 & 0.81 & 0.75 & 0.78 & 0.94 & 0.75 & 0.84 \\
1.03 & 1.06 & 0.88 & 0.81 & 0.69 & 0.63 & 0.97 & 0.84 & 0.91 & 0.94 \\
1 & 0.88 & 0.75 & 0.78 & 0.75 & 0.78 & 1.03 & 0.94 & 0.78 & 0.94 \\
0.88 & 1 & 0.78 & 0.72 & 0.81 & 0.75 & 0.97 & 0.84 & 0.84 & 0.81 \\
0.94 & 1.12 & 0.72 & 0.81 & 0.81 & 0.66 & 0.75 & 0.88 & 0.94 & 0.75 \\
1.25 & 0.94 & 0.69 & 0.66 & 0.84 & 0.72 & 0.81 & 0.94 & 0.88 & 0.69 \\
0.94 & 0.83 & 0.82 & 1 & 1.06 & 1 & 1.18 & 1 & 0.94 & 0.82 \\
1.18 & 1 & 1 & 1.06 & 1.24 & 0.82 & 0.82 & 0.94 & 1.12 & 0.88 \\
0.94 & 0.83 & 1 & 0.71 & 1.06 & 0.94 & 1.06 & 0.82 & 1.18 & 0.76 \\
0.94 & 0.83 & 0.94 & 0.94 & 0.82 & 1 & 1 & 0.82 & 0.88 & 0.71 \\
1.06 & 0.92 & 0.88 & 1.12 & 0.94 & 0.82 & 0.76 & 1.12 & 0.82 & 0.82 \\
0.94 & 1.04 & 1 & 0.94 & 0.94 & 1.06 & 1 & 0.82 & 1 & 0.76 \\
1 & & 0.92 & 1 & 0.83 & 1.04 & 0.83 & 1.04 & 1 & 1 \\
1.04 & & 0.92 & 1 & 0.75 & 1 & 0.92 & 1.21 & 1 & 0.83 \\
0.92 & & 1 & 0.83 & 0.75 & 1 & 0.75 & 1.04 & 1 & 0.92 \\
0.92 & & 0.92 & 0.75 & 1 & 1.12 & 1 & 1 & 1.04 & 1 \\
1.13 & & 1 & 1 & 0.75 & 0.92 & 0.92 & 1 & 0.83 & 0.75 \\
1 & & 0.92 & 0.92 & 0.75 & 1.04 & 1 & 1 & 1 & 1 \\
\hline
\end{tabular}


PRO cells D3.

Control 5 mGy 10 mGy 20 mGy 50 mGy 100 mGy 200 mGy 250 mGy

\begin{tabular}{llllllll}
\hline .04 & 0.95 & 0.96 & 0.86 & 0.72 & 0.88 & 0.9 & 0.72
\end{tabular}

$1.2 \quad 1$

$1.05-0.88$

$\begin{array}{lll}1.04 & 0.86 & 0.8\end{array}$

0.88

$\begin{array}{llll}1.28 & 1 & 0.8 & 0.9 \\ 0.88 & 1.05 & 0.95 & 0.72\end{array}$

$\begin{array}{llll}1.04 & 0.85 & 0.95 & 0.92\end{array}$

$\begin{array}{llll}0.8 & 0.85 & 0.86 & 0.72\end{array}$

0.88

10

110.96

12

130.9

$14 \quad 1.05$

1.1

$15 \quad 0.95$

$16 \quad 0.92$

$\begin{array}{ll}17 & 1.1 \\ 18 & 0.98\end{array}$

$8 \quad 0.92$

191

$\begin{array}{ll}20 & 1.17 \\ & 0.92\end{array}$

$\begin{array}{llllll}21 & 0.92 & 1 & 0.91 & 0.95\end{array}$

$\begin{array}{llll}0.92 & 1.07 & 1.22 & 0.95\end{array}$

$\begin{array}{lllll}24 & 1.04 & 1.19 & 1 & 1.95 \\ & 1 & 0.9 & 1 & 1.19\end{array}$

1

0.92

$27 \quad 0.83$

$28 \quad 1.17$

$29 \quad 1.09$

$30 \quad 1.13$

$31 \quad 0.83$

$32 \quad 1.09$

$33 \quad 0.96$

$34 \quad 0.83$

$35 \quad 1$

$36 \quad 0.96$

$37 \quad 0.87$

$38 \quad 1.09$

$39 \quad 0.87$

$40 \quad 0.96$

$41 \quad 1.07$

$42 \quad 0.95$

$43 \quad 0.98$

$44 \quad 1$

$45 \quad 1.07$

$\begin{array}{ll}46 & 0.9 \\ & 1.09\end{array}$

$47 \quad 1$

$48 \quad 0.95$

$49 \quad 0.98$

$\begin{array}{ll}40 & 1 \\ 50 & 0.95\end{array}$

$51 \quad 0.95$

$\begin{array}{ll}51 & 0.98 \\ 52 & 0.95\end{array}$

$53 \quad 1.07$

54

55

56

57

58
PRO cells D4.

Control 2.5 mGy 5 mGy 10 mGy 25 mGy 50 mGy 75 mGy 100 mGy

\begin{tabular}{llllllll}
\hline 1.1 & 0.96 & 0.74 & 0.96 & 0.74 & 0.96 & 0.9 & 0.74 \\
0.96 & 0.92 & 0.74 & 0.81 & 0.81 & 0.89 & 0.9 & 0.81 \\
1.1 & 0.96 & 0.89 & 0.74 & 0.74 & 0.96 & 0.76 & 0.81 \\
0.89 & 0.81 & 0.81 & 0.74 & 0.96 & 0.81 & 0.88 & 0.89 \\
1.04 & 1.1 & 1.04 & 0.81 & 0.74 & 0.89 & 0.86 & 0.81 \\
0.93 & 0.92 & 0.89 & 0.78 & 0.78 & 0.81 & 0.9 & 0.85 \\
1.05 & 0.95 & 1.05 & 0.9 & 1 & 0.95 & & 0.95 \\
1 & 0.86 & 1.05 & 0.95 & 0.86 & 0.9 & & 0.86 \\
1.1 & 0.9 & 1 & 0.95 & 1 & 0.93 & & 0.9 \\
1.1 & 0.95 & 0.95 & 1 & 0.95 & 0.95 & & 0.88 \\
0.86 & 0.9 & 0.9 & 1 & 1.05 & 0.93 & & 0.86 \\
0.9 & 0.9 & 0.93 & 0.81 & 1.05 & 0.9 & & \\
\end{tabular}

60

63

64

65

66

67

68

69

71

72

73

74

75

76

77

78

79

80

PRO cells D5.

\begin{tabular}{lllllll}
\hline Control & $0.025 \mathrm{mGy}$ & $0.05 \mathrm{mGy}$ & $0.1 \mathrm{mGy}$ & $0.2 \mathrm{mGy}$ & $0.5 \mathrm{mGy}$ & $1 \mathrm{mGy}$ \\
\hline 1.17 & & 0.91
\end{tabular}

\begin{tabular}{llllllll}
\hline 1.17 & 0.91 & 0.78 & 1.09 & 1.04 & 1.04 & 0.91 & 82
\end{tabular}

$\begin{array}{llllllll}1.04 & 0.87 & 1.04 & 0.83 & 1.04 & 0.96 & 0.91 & 83\end{array}$

$\begin{array}{llllllll}1.09 & 0.83 & 1.04 & 0.91 & 0.91 & 0.78 & 0.74 & 84 \\ 1.13 & 0.87 & 1.04 & 1 & 0.96 & 0.87 & 0.83 & 8\end{array}$

$\begin{array}{llllllll}1.04 & 0.91 & 0.87 & 0.87 & 1.13 & 0.87 & 1.09 & 85\end{array}$

$\begin{array}{llllllll}0.83 & 0.87 & 1 & 0.96 & 0.96 & 0.78 & 1 & 86\end{array}$

$\begin{array}{llllllll}1.09 & 1.17 & 0.91 & 0.78 & 0.96 & 1 & 0.65 & 87\end{array}$

$\begin{array}{llllllll}0.96 & 0.96 & 0.83 & 0.96 & 0.83 & 0.91 & 0.91 & 87 \\ 1.13 & 0.91 & 1.04 & 1 & 0.87 & 0.91 & 0.87 & 88\end{array}$

$\begin{array}{llllllll}0.83 & 0.78 & 0.87 & 0.65 & 0.87 & 0.96 & 0.96 & 89\end{array}$

$\begin{array}{llllllll}1 & 0.65 & 1.09 & 0.74 & 1.04 & 0.61 & 0.91 & 90\end{array}$

$\begin{array}{llllllll}0.96 & 0.96 & 0.83 & 0.74 & 0.87 & 0.78 & 0.87 & 90.96\end{array}$

$\begin{array}{llllllll}0.83 & 1.14 & 1.05 & 1.12 & 1.02 & 0.98 & 1.07 & 91\end{array}$

$\begin{array}{llllllll}0.87 & 1.02 & 1.02 & 1 & 1 & 0.98 & 1 & 92\end{array}$

$\begin{array}{llllllll}1.09 & 0.93 & 1.07 & 1.19 & 1.07 & 0.95 & 1.1 & 93\end{array}$

$\begin{array}{llllllll}0.87 & 0.98 & 1 & 0.95 & 1 & 1.14 & 1.02 & 94 \\ 1 & 0.9 & 1.02 & 1.07 & 0.95 & 1 & 1 & 94\end{array}$

$\begin{array}{llllllll}1 & 0.9 & 1.02 & 1.07 & 0.95 & 1 & 1 & 94 \\ 0.96 & 1.12 & 1.07 & 1 & 0.95 & 1 & 1.05 & 95\end{array}$

$\begin{array}{llllllll}1.07 & 0.94 & 1 & 0.7 & 1.03 & 0.9 & 0.7 & 96 \\ 0.95 & 1.03 & 0.7 & 1 & 1.03 & 0.9 & 0.7 & 97\end{array}$

$\begin{array}{llllllll}0.95 & 1.03 & 0.7 & 1 & 1.03 & 0.9 & 0.7 & 97 \\ 0.95 & 1.13 & 0.6 & 0.95 & 1 & 0.95 & 0.7 & 97\end{array}$

$\begin{array}{llllllll}0.95 & 1.13 & 0.6 & 0.95 & 1 & 0.95 & 0.7 & 97 \\ 1.24 & 0.86 & 0.6 & 0.7 & 1.03 & 0.85 & 0.8 & 98\end{array}$

$\begin{array}{llllllll}1.24 & 0.84 & 0.75 & 0.8 & 1.06 & 0.8 & 0.75 & 99\end{array}$

$\begin{array}{llllllll}1 & 0.96 & 0.85 & 0.95 & 1.03 & 0.9 & 0.85 & 99 \\ 1.07 & & 1.13 & 1.23 & & 1.08 & 1.23 & 100\end{array}$

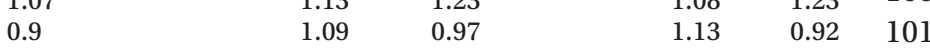

$\begin{array}{llllll}1.09 & 0.97 & 0.87 & 1.18 & 0.97 & 102\end{array}$

$\begin{array}{llllll}1 & 0.97 & 1.03 & 0.92 & 1.13 & 102 \\ 0.95 & 0.92 & 1.13 & 1.23 & 1.08 & 103\end{array}$

$\begin{array}{llllll}0.98 & 0.94 & 1.18 & 1.03 & 1.03 & 104\end{array}$

$1+105$

$\begin{array}{ll}0.95 & 106\end{array}$

$0.98-107$

$0.95+108$

$1.07 \quad 109$

1.2

0.8

1.1

0.9

1.02

0.97

0.92

1.13

0.97

110

111

112

113

114

115

116

117

118 
PRO cells D6.

\begin{tabular}{|c|c|c|c|c|c|c|}
\hline Control & $0.25 \mathrm{uGy}$ & 0.5 uGy & $1 \mathrm{uGy}$ & $2 \mathrm{uGy}$ & $5 \mathrm{uGy}$ & $10 \mathrm{uGy}$ \\
\hline 1 & 1 & 0.85 & 0.45 & 0.95 & 0.9 & 0.9 \\
\hline 1 & 0.95 & 0.75 & 0.7 & 1.12 & 0.8 & 0.8 \\
\hline 1.2 & 1.07 & 0.65 & 0.75 & 1.07 & 0.95 & 0.6 \\
\hline 0.8 & 1 & 0.85 & 0.7 & 1 & 0.7 & 0.7 \\
\hline 1.1 & 0.83 & 0.65 & 0.65 & 0.98 & 0.95 & 0.7 \\
\hline 0.9 & 0.95 & 0.85 & 0.5 & 1.14 & 0.8 & 0.9 \\
\hline 1.07 & 1 & 1.07 & 1 & 1.05 & 0.9 & 1.05 \\
\hline 0.95 & 0.8 & 1.05 & 1 & 0.95 & 1 & 1.1 \\
\hline 0.95 & 1 & 0.95 & 0.98 & 0.8 & 0.95 & 1.1 \\
\hline 0.98 & 0.9 & 1.05 & 0.95 & 0.9 & 0.93 & 0.98 \\
\hline 1.24 & 0.85 & 0.98 & 0.86 & 0.9 & 0.95 & 1.02 \\
\hline 1 & 0.8 & 0.9 & 0.88 & 0.9 & 0.95 & 1.05 \\
\hline 1.07 & & 0.85 & 1 & & 1.05 & 0.9 \\
\hline 0.9 & & 0.75 & 1.05 & & 0.95 & 1 \\
\hline 1.09 & & 0.9 & 0.95 & & 0.95 & 0.95 \\
\hline 1 & & 1 & 0.8 & & 1 & 0.85 \\
\hline 0.95 & & 1 & 0.85 & & 0.9 & 0.9 \\
\hline 0.98 & & 0.9 & 0.9 & & 0.8 & 0.8 \\
\hline \multicolumn{7}{|l|}{1} \\
\hline \multicolumn{7}{|l|}{0.95} \\
\hline \multicolumn{7}{|l|}{0.95} \\
\hline \multicolumn{7}{|l|}{0.98} \\
\hline \multicolumn{7}{|l|}{0.95} \\
\hline \multicolumn{7}{|l|}{1.07} \\
\hline \multicolumn{7}{|l|}{0.9} \\
\hline \multicolumn{7}{|l|}{1.1} \\
\hline \multicolumn{7}{|l|}{1.2} \\
\hline \multicolumn{7}{|l|}{1} \\
\hline \multicolumn{7}{|l|}{0.9} \\
\hline 0.9 & & & & & & \\
\hline
\end{tabular}

REG cells D6.

\begin{tabular}{|c|c|c|c|c|c|}
\hline Control & $0.5 \mathrm{uGy}$ & $1 \mathrm{uGy}$ & $2 \mathrm{uGy}$ & 5 uGy & $10 \mathrm{uGy}$ \\
\hline 1.09 & 0.85 & 1.21 & 1.23 & 1.03 & 0.85 \\
\hline 0.97 & 1.21 & 1.15 & 0.85 & 1.21 & 1.03 \\
\hline 1.03 & 0.73 & 1.27 & 1.23 & 0.97 & 1.21 \\
\hline 0.97 & 0.97 & 1.39 & 0.85 & 1.03 & 1.27 \\
\hline 1.09 & 0.85 & 1.33 & 0.92 & 1.27 & 1.51 \\
\hline 0.85 & 0.96 & 1.09 & 1.15 & 0.97 & 0.97 \\
\hline 0.73 & 1.15 & 1.08 & 1.08 & 1.08 & 1.08 \\
\hline 0.92 & 1.15 & 1.23 & 0.85 & 1.23 & 1.08 \\
\hline 0.85 & 1.23 & 0.92 & 1.08 & 0.92 & 1.08 \\
\hline 0.92 & 1.08 & 0.88 & 1.15 & 0.81 & 1.15 \\
\hline 1 & 1.15 & 1.15 & 1.08 & 0.92 & 1.27 \\
\hline 1.15 & 0.85 & 1.15 & & 1 & 1.04 \\
\hline 0.92 & 1 & 1.08 & & 0.85 & 1.15 \\
\hline 1 & 1 & 1.23 & & 1.15 & 1.08 \\
\hline 1.23 & 1.15 & 1.23 & & 1.23 & 0.95 \\
\hline 1.15 & 1.15 & 0.85 & & 1 & 1.14 \\
\hline 1 & 1 & 1 & & 1.14 & 1.33 \\
\hline 1 & 1.31 & & & 1.33 & 0.95 \\
\hline 0.86 & & & & 0.95 & 0.95 \\
\hline 0.76 & & & & 0.95 & 0.95 \\
\hline 0.81 & & & & 1.14 & \\
\hline 0.81 & & & & 0.95 & \\
\hline \multicolumn{6}{|l|}{0.86} \\
\hline \multicolumn{6}{|l|}{1.05} \\
\hline \multicolumn{6}{|l|}{1.33} \\
\hline \multicolumn{6}{|l|}{1.24} \\
\hline \multicolumn{6}{|l|}{0.95} \\
\hline \multicolumn{6}{|l|}{1.14} \\
\hline \multirow{2}{*}{\multicolumn{6}{|c|}{$\begin{array}{l}1.14 \\
1.14\end{array}$}} \\
\hline & & & & & \\
\hline
\end{tabular}

60 61 62 63 64 65 66 67 68 69 70 71 72 73 74 75 76 77 78 79 80

REG cells D3. 